\title{
Dermatology
}

Published online: July 25, 2008

Dermatology 2008;217:250-251

DOI: $10.1159 / 000148253$

\section{Dermoscopic Features of Clear Cell Hidradenoma}

Yuichi Yoshida, Keiko Nakashima, Osamu Yamamoto

Division of Dermatology, Department of Medicine of Sensory and Motor Organs, Faculty of Medicine, Tottori University, Yonago, Japan

Key Words

Dermoscopy $\cdot$ Nodular hidradenoma $\cdot$ Sweat gland

Clear cell hidradenoma is an uncommon benign cutaneous neoplasm [1]. Clinically, it might be difficult to make a correct diagnosis of this tumor because its differential diagnosis includes various adnexal tumors. However, to date little has been known about the dermoscopic features of clear cell hidradenoma. Herein, we describe possible dermoscopic features of clear cell hidradenoma.

An 88-year-old woman presented with a 4-month history of a nodule on her right knee. It enlarged gradually in size, and occa- sional bleeding was also noted. Physical examination revealed an $11 \times 8 \mathrm{~mm}$, dome-shaped, flesh-colored nodule with ulceration on its surface (fig. 1). On dermoscopy, amorphous whitish areas with some linear or hairpin-like vessels were seen at the periphery. Reddish purple areas were also present (fig. 2). The nodule was surgically excised under local anesthesia. Histologically, the tumor was composed of solid tumor cell nests with abundant cystic spaces or ductal structures. In solid nests, many clear cells and some slightly dark cells were seen. Most of the cystic spaces contained homogenous eosinophilic material, and some of them were filled with red blood cells (fig. 3). Based on these findings, a diagnosis of clear cell hidradenoma was made.

Clear cell hidradenoma, also known as nodular hidradenoma or solid cystic hidradenoma, occurs most commonly on the head, neck and anterior trunk [2]. Ulceration is seen occasionally [3]. Histologically, the tumor is composed of a lobulated mass of clear cells and various-sized tubular laminae and abundant cystic spaces.

Dermoscopy is now widely used as a tool to diagnose many pigmented and nonpigmented cutaneous tumors [4]. In the present case, dermoscopic examination revealed reddish purple areas and some linear or hairpin-like vessels on the surface of the tu-

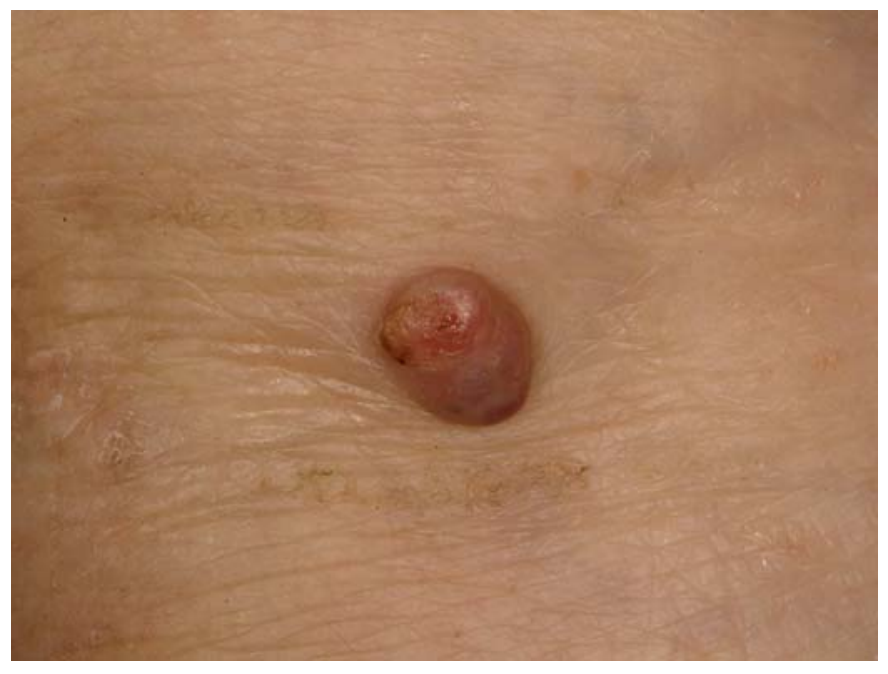

Fig. 1. A dome-shaped, flesh-colored nodule with ulceration.

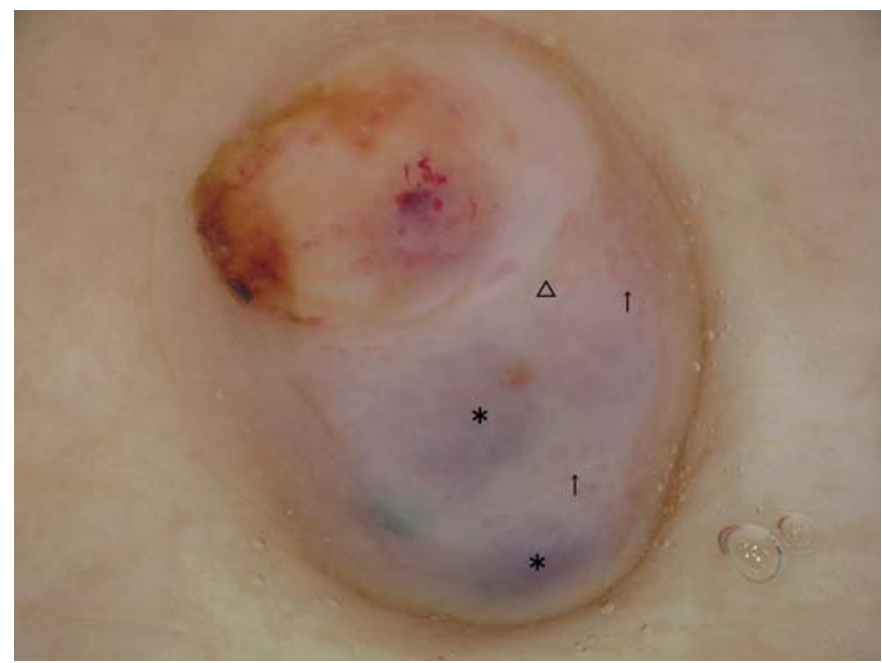

Fig. 2. On dermoscopy, amorphous whitish (arrowhead) areas with some linear vessels and hairpin vessels (black arrows) were seen. Reddish purple areas were also present (asterisks).

\section{KARGER}

\section{(C) 2008 S. Karger AG, Base}

Fax +41 613061234 E-Mail karger@karger.ch www.karger.com 


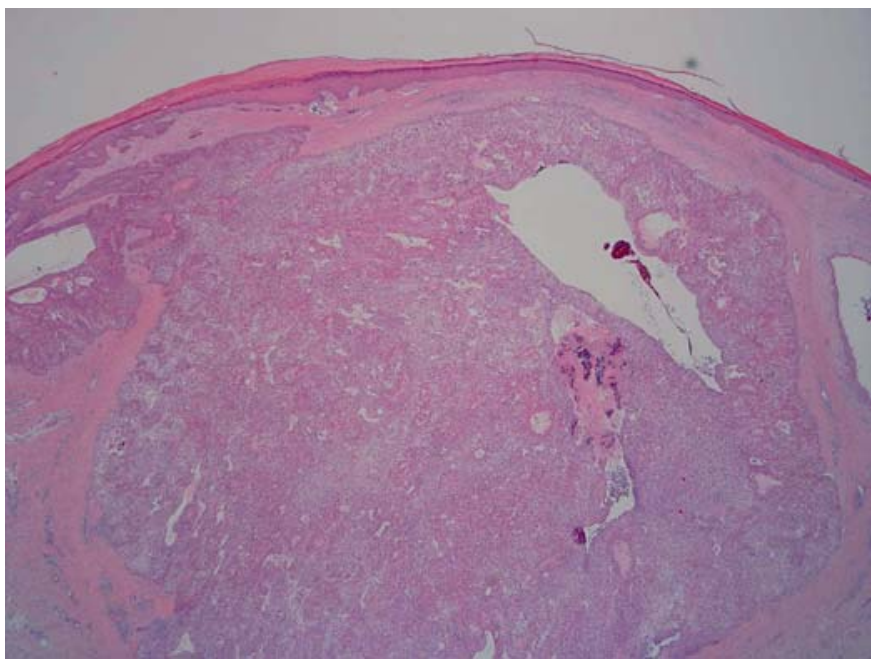

Fig. 3. The tumor was mainly composed of clear cells and contained abundant cystic spaces and ductal structures with hemorrhage. Hematoxylin-eosin. $\times 200$.

mor. It has been reported that polymorphous vascular patterns were seen in various benign or malignant skin tumors $[5,6]$. However, it is of interest that dermoscopic reddish purple areas seemed to correspond to cystic spaces with hemorrhage histologically. The dermoscopic features of our case were clearly different from those of hemangioma, pyogenic granuloma or poroma. Although we could not find any dermoscopic findings of clear cell hidradenoma in the English literature, similar reddish purple areas were reported to be seen in 2 cases of clear cell hidradenoma in a Japa- nese textbook of dermoscopy [7]. We have reviewed 18 cases of clear cell hidradenoma in our laboratory. Remarkably, hemorrhage in cystic spaces was observed in 11 of 16 cases $(68.8 \%)$ histologically (not shown). Therefore, we speculate that hemorrhage may be caused easily in clear cell hidradenoma by mechanical trauma, resulting in reddish purple areas on dermoscopy. Our findings could constitute a clue for the diagnosis of clear cell hidradenoma.

\section{References}

1 Stratigos AJ, Olbright S, Kwan TH, Bowers KE: Nodular hidradenoma: a report of three cases and review of the literature. Dermatol Surg 1998; 24:387-391.

2 Hernandez-Perez E, Cestoni-Parducci R: Nodular hidradenoma and hidradenocarcinoma. J Am Acad Dermatol 1985;12:15-20.

-3 Schweitzer WJ, Goldin HM, Bronson DM, Brody PE: Ulcerated tumor on the scalp: clear cell hidradenoma. Arch Dermatol 1989;125:985986.

4 Kittler H, Pehamberger H, Wolff K, et al: Diagnostic accuracy of dermoscopy. Lancet Oncol 2002;3:159-165.

5 Nicolino R, Zalaudek I, Ferrara G, et al: Dermoscopy of eccrine poroma. Dermatology 2007;215:160-163.

-6 Pizzichetta MA, Talamini R, Stanganelli I, et al: Amelanotic/hypomelanotic melanoma: clinical and dermoscopic features. $\mathrm{Br} J$ Dermatol 2004;150:1117-1124

7 Ohara K: Nodular hidradenoma; in Saida T, Ohara K, Tsuchida T, Tanaka K (eds): Color Atlas of Dermoscopy (in Japanese). Tokyo, Kanehara, 2003, p 168.

Yuichi Yoshida, MD

Division of Dermatology

Department of Medicine of Sensory and Motor Organs

Faculty of Medicine, Tottori University, 86 Nishi-cho

Yonago-shi, Tottori 683-8503 (Japan)

Tel. +81 85938 6597, Fax +81 859386599

E-Mail yxy@grape.med.tottori-u.ac.jp 